\title{
Application of Time Series InSAR (SBAS) Method using Sentinel-1A Data for Land Subsidence Detection in Surabaya City
}

\author{
Ira Mutiara Anjasmara ${ }^{\# *}$, Sendy Ayu Yulyta ${ }^{\#}$, Muhammad Taufik ${ }^{\#}$ \\ ${ }^{\#}$ Department of Geomatics Engineering, Institut Teknologi Sepuluh Nopember, Kampus ITS Sukolilo, Surabaya, 60111, Indonesia \\ E-mail:*ira@geodesy.its.ac.id
}

\begin{abstract}
We studied land subsidence occurrence in Surabaya, considering the rapid urban growth in the city. It is evidenced by the increasing number of buildings (e.g., houses, apartments, offices) that have been realized before 2015 and the increasing transport activities in the industrial area. Land subsidence is a vertical deformation on the land surface that can be caused by landslides, earthquakes, soil consolidation process, or even human-made activities, depending on the material characteristics of the area. In this study, Time-series InSAR (TS-InSAR), specifically the Small Baseline Subset (SBAS) method, is applied to obtain the Line-of-Sight (LOS) velocities and time-series LOS displacements in Surabaya between May 2015 and September 2017. We used 28 Sentinel-1A data (IW mode) acquired by using Terrain Observation with Progressive Scan (TOPS) operation with the spatial resolution of $5 \times 20$ $m$ and covers the area of $250 \mathrm{~km}^{2}$. DEM SRTM with $30 \mathrm{~m}$ spatial resolution was used to reduce topography effect contribution in the interferograms. Based on the SBAS method, interferogram pair selection is applied with the maximum value of $150 \mathrm{~m}$ for the perpendicular baseline and 100 days for the temporal baseline. The DInSAR process successfully generated seventy-four (74) interferogram pairs, and then by using SBAS algorithm, the LOS velocity and time-series LOS displacement were estimated. The results showed the varying displacements respond with the significant subsidence occurred in the North, East, and Southeast part of Surabaya. The SBAS result confirmed that the LOS velocity over the Surabaya area between May 2015 and September 2017 ranges from -40 to $+30 \mathrm{~mm} / \mathrm{year}$. Significant land subsidence occurred in the Asemrowo area (North Surabaya) with the value of LOS displacement velocity up to $-45 \mathrm{~mm} / \mathrm{yr}$.
\end{abstract}

Keywords — land subsidence; SBAS method; sentinel-1A; LOS velocity; time-series LOS displacement.

\section{INTRODUCTION}

Ground or surface deformation is the situation when the land surface changes horizontally and vertically. It is caused by many factors such as earthquakes, landslides, surface loads, groundwater extraction, and geological induced caused. In Surabaya, the risk of deformation in Surabaya is caused by the increasing load of buildings and the compression of the unconsolidated alluvium layer that dominated the Surabaya area. Typically, the deformation that occurred in Surabaya is local but could interfere the human safety if it occurs continuously. Vertical deformation presents in two responses, namely land subsidence and uplift. Its impact shows in small to high level depends on the material characteristics of the area.

Surabaya is the second-largest city in Indonesia that has been rapidly growing. It is evidenced by the presence of tens of thousands of building units that have been realized before 2015. The land-use in Surabaya has changed significantly. For example, in East Surabaya, the number of ponds has decreased and changed to becoming residences and industrial areas. The number of high-rise buildings such as apartments, hotels, and offices also increasing, especially in the East and West parts of Surabaya. On the other hand, the geological condition showed that the soil type of Surabaya is dominated by alluvium. The alluvium layers are still in consolidation and compaction process so that the subsidence would quickly happen if the load on the surface is increasing significantly.

Observation methods to monitor deformation have been developed in Geodesy field. Leveling is the most accurate method to observe vertical deformation. However, the technique is only practical to be applied in a small coverage area because it is costly and time-consuming. Global Positioning System (GPS) is another geodetic technique that can be effectively used to monitor deformation. Nevertheless, by using the GPS techniques to monitor deformation of large areas, lots of number of observation points are needed. In recent years, Interferometric Synthetic Aperture Radar (InSAR) method has been widely used to detect early ground deformation [1]-[3]. InSAR is beneficial to detect and monitor a regional-scale ground deformation at two times in the same area with a centimeter of accuracy [4], [5]. However, InSAR has a problem due to the variety of 
scatterer between two times [6], [7], atmospheric signal delay, temporal, and spatial decorrelation. A new method called Time-Series InSAR (TS-InSAR) method is proposed to overcome the previously mentioned limitations. To generate the displacement velocity, TS-InSAR can be performed in two ways, namely Persistent Scatterer InSAR (PS-InSAR) and Small Baseline Subset (SBAS). The SBAS method effectively mitigates the decorrelation phenomena by analyzing high coherence distributed scatterers (DS) based on small baseline interferograms combination [8]. Using the SBAS method, temporal variations of the Line of Sight (LOS) signal and time-series accumulated displacement can be generated [8]-[10].

In order to raise the capability of the SBAS method, data with short revisit time is needed to produce such a large stack combination. We used 28 Sentinel-1A data in Interferometric Wide (IW) mode that are acquired by using the Terrain Observation with Progressive Scans (TOPS) operation [11]. Sentinel-1A provides a swath width of 250 $\mathrm{km}^{2}$ with $5 \mathrm{~m} \times 20 \mathrm{~m}$ of spatial resolution and a temporal resolution of 12 days [12]. Single Look Complex (SLC) of Sentinel-1A products are used as the secondary data to the applied the SBAS method.

In this study, we first processed the Sentinel-1A data using conventional DInSAR and then proceed with the TSInSAR processing by using the SBAS algorithm. The conventional DInSAR produced 74 interferogram pairs, and the SBAS method generated 28 accumulative LOS displacements and LOS displacement. In the analysis, we focused on the area that significantly experience subsidence, namely Kenjeran and Gunung Anyar Tambak (residential area); Asemrowo (industrial area); and Gunung Anyar (mudflow manifestation). As we suspect that the subsidence in Surabaya is triggered by the alluvium soil domination and the urban growth, we also linked this phenomenon with the geological maps and the field conditions.

\section{A. Study Area}

Surabaya is the capital city of East Java, Indonesia. The city is in $415 \mathrm{~km}$ from West of Bali Island and $796 \mathrm{~km}$ from the East of Jakarta, the capital of Indonesia. Geographically, Surabaya is situated on the latitude of $7^{\circ} 12^{\prime} \mathrm{S}-7^{\circ} 21^{\prime} \mathrm{S}$ and the longitude of $112^{\circ} 35^{\prime} \mathrm{E}-112^{\circ} 51^{\prime} \mathrm{E}$. The North and East part of Surabaya are surrounded by Madura strait, while the West and South parts are adjacent to Gresik and Sidoarjo, respectively. Surabaya is the second-largest city in Indonesia, with the total area is about $350 \mathrm{~km} 2$ and a population of 2.7 million people. Geologically, Surabaya is dominated by Alluvium plain that still in consolidation and compaction process (Fig. 1). Asemworo and Benowo region are the industrial and warehousing area; there were 32 of industries has been recorded [13]. Furthermore, the increasing number of high-rise buildings and housing developments have increased significantly. Land-use change also occurred in East Surabaya, where the fishponds and mangrove areas are decreasing and transform into settlement areas.

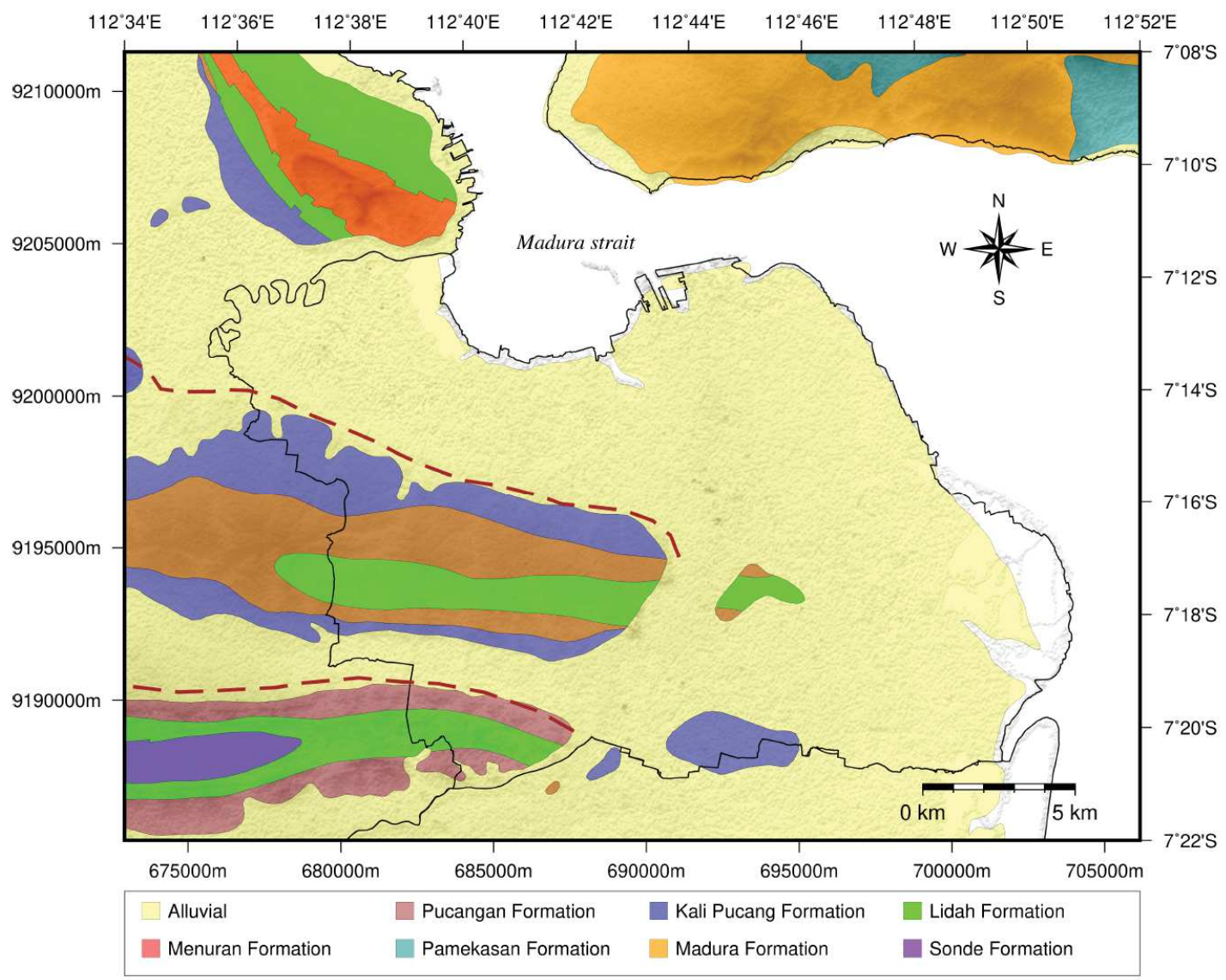

Fig.1 Geology map of Surabaya and its surroundings (modified from [17] 


\section{B. Data Set}

We use Sentinel-1A Level-1 SLC products that were downloaded free by online access from Sentinel-1 Scientific Data Hub. The satellite flies along the ascending pass with the antenna looking down to the right. The incidence angle of the Sentinel-1A is approximately $38^{\circ}$. The Sentinel-1A instrument onboard operates the C-band wavelength (5.6 $\mathrm{cm})$. We used the 28 data of Sentinel-1A between 25 May 2015 and 11 September 2017 (Fig. 2). The data dated 26 June 2016 was chosen as a master (red dot), whereas the others are slaves (black dots). TABLE I shows the 28 data we used with the perpendicular and temporal baseline relative to the master. We also used the geology map of Surabaya (Fig. 1) to investigate the relationship between subsidence and the soil types. To relate the deformation area and how its condition in the field, we also do the site visit in the selected area.

TABLE II

THE SENTINEL-1A DATA USED IN THIS STUDY

\begin{tabular}{|c|c|c|c|c|}
\hline \multirow[b]{2}{*}{ No. } & \multirow{2}{*}{$\begin{array}{l}\text { Acquisitions } \\
\text { Time }\end{array}$} & \multirow{2}{*}{$\begin{array}{c}\text { Absolute } \\
\text { Orbit \# }\end{array}$} & \multicolumn{2}{|c|}{ Baseline } \\
\hline & & & $\begin{array}{r}\text { Perpendicular } \\
(\mathbf{m})\end{array}$ & $\begin{array}{r}\text { Temporal } \\
\text { (days) }\end{array}$ \\
\hline 1 & $25-05-2015$ & 6076 & -23.098 & 384 \\
\hline 2 & 18-06-2015 & 6426 & 34.950 & 360 \\
\hline 3 & $12-07-2015$ & 6776 & 64.636 & 336 \\
\hline 4 & 29-08- 2015 & 7476 & -17.529 & 288 \\
\hline 5 & $22-09-2015$ & 7826 & 4.634 & 264 \\
\hline 6 & $16-10-2015$ & 8176 & -24.431 & 240 \\
\hline 7 & 09-11-2015 & 8526 & 89.926 & 216 \\
\hline 8 & $27-12-2015$ & 9226 & -46.703 & 168 \\
\hline 9 & $20-01-2016$ & 9576 & 28.942 & 144 \\
\hline 10 & $13-02-2016$ & 9926 & 37.268 & 120 \\
\hline 11 & 08-03-2016 & 10276 & -14.264 & 96 \\
\hline 12 & $25-04-2016$ & 10976 & -2.211 & 48 \\
\hline 13 & $19-05-2016$ & 11326 & 55.403 & 24 \\
\hline 14 & 12-06-2016 & 11676 & $\mathbf{0}$ & 0 \\
\hline 15 & $06-07-2016$ & 12026 & -29.133 & -24 \\
\hline 16 & $23-08-2016$ & 12726 & -25.098 & -72 \\
\hline 17 & $16-09-2016$ & 13076 & 35.430 & -96 \\
\hline 18 & $10-10-2016$ & 13426 & -23.891 & -120 \\
\hline 19 & 27-11-2016 & 14126 & 0.149 & -168 \\
\hline 20 & $21-12-2016$ & 14476 & 0.554 & -192 \\
\hline 21 & 14-01-2017 & 14826 & -23.818 & -216 \\
\hline 22 & $15-02-2017$ & 15701 & -19.421 & -276 \\
\hline 23 & $20-03-2017$ & 16226 & -22.078 & -312 \\
\hline 24 & 26-05-2017 & 16751 & 43.489 & -348 \\
\hline 25 & 19-06-2017 & 17101 & -4.548 & -372 \\
\hline 26 & $25-07-2017$ & 17626 & 39.941 & -408 \\
\hline 27 & $18-08-2017$ & 17976 & 2.792 & -432 \\
\hline 28 & 11-09-2017 & 18326 & -12.416 & -456 \\
\hline
\end{tabular}

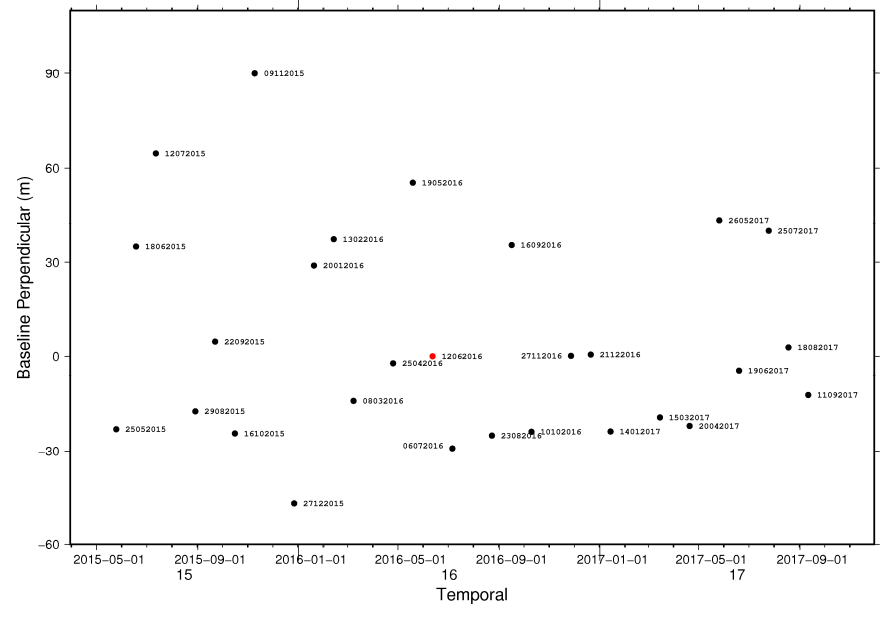

Fig. 2 The Orbit Position Plot of the 28 Sentinel-1A Dataset

\section{MATERIAL AND METHOD}

The processing method used in this study is presented as a flow chart in Fig. 3. The first step is co-registration; it makes all images geometrically consistent with the super master image. The precise orbit and metadata information from all Sentinel-1A data were used to estimates the orbit position, as shown in Fig. 2. To be used in the processing, the DEM coordinate system (latitude, longitude) must be converted to the radar coordinate system (range, azimuth).

The second step is data pair selection to generates differential interferograms. We select and combine the data based on a multiple-master. From 28 Sentinel-1A images, we have selected 74 pairs, as shown in Fig. 3. These combinations were based on a small baseline strategy, which chooses the perpendicular baseline between two images less than $150 \mathrm{~m}$ and a temporal baseline less than 100 days. Then, we processed all the data pairs by using the conventional DInSAR method to generate 74 interferograms. To reduce the speckle noise, we applied phase filtering. To reduce topography effects, the converted DEM was used as a reference for topography. The precise orbit and metadata information is used to estimates the flat earth phase contribution due to the earth's curvature.

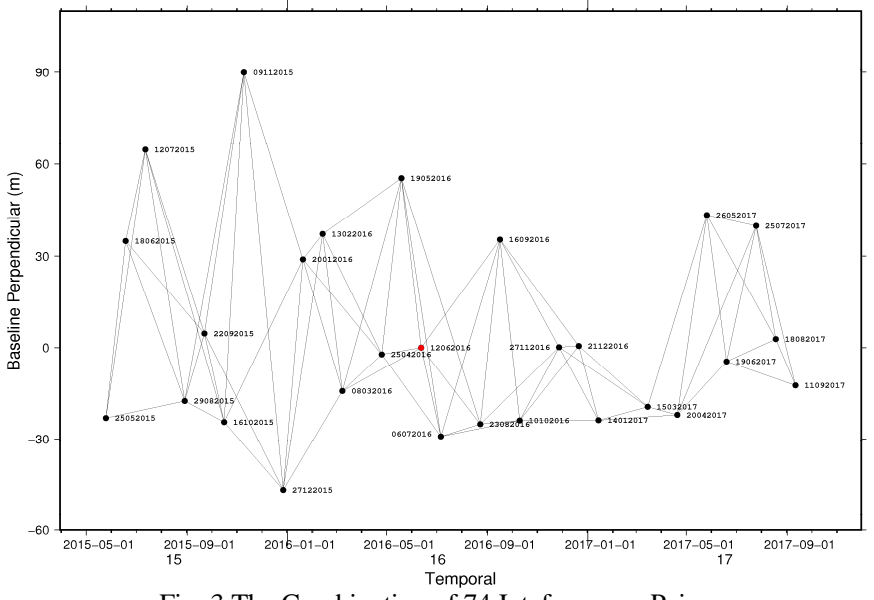

Fig. 3 The Combination of 74 Inteferogram Pairs 


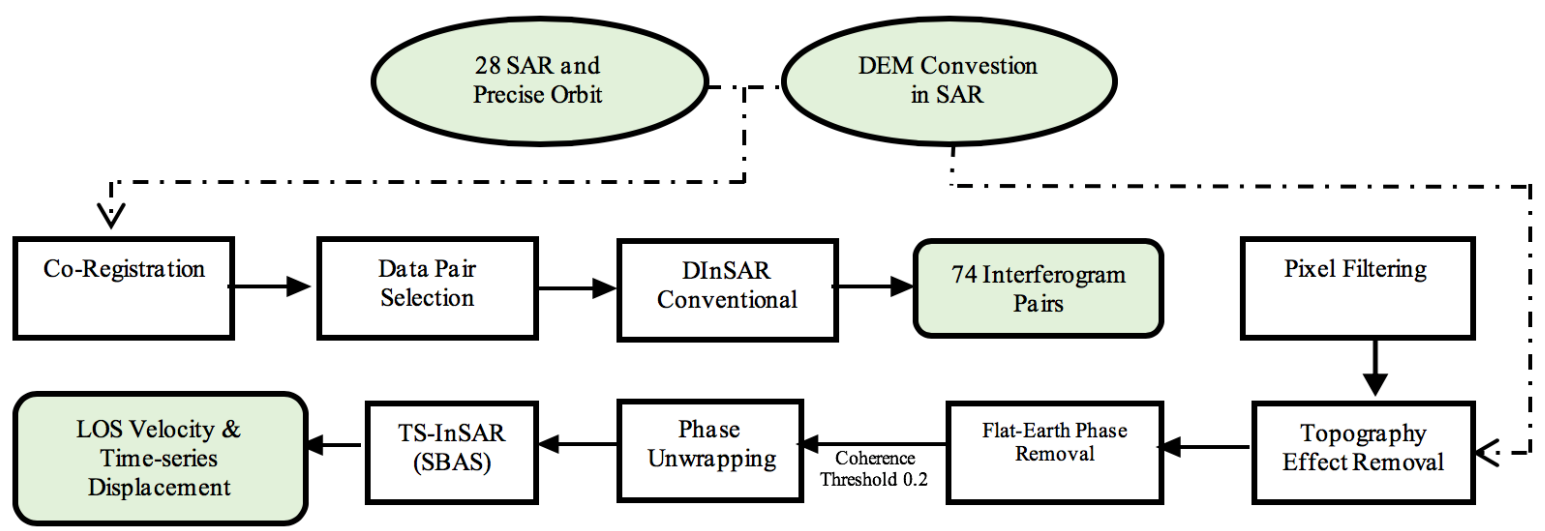

Fig. 4 The Flow Chart of Time-series InSAR (SBAS) Method

Low coherence in interferogram corresponds to an increase in the noise level of the InSAR phase measurements. InSAR processing systems commonly use a coherence threshold to mask out noisy pixels. We used a coherence threshold of 0.2 so that the coherence pixel less than 0.2 will be masked out. Each of the interferograms consists of the phase contributions due to orbit, atmospheric signal delay, topography, and deformation. These problems could be reduced by phase unwrapping processing, which removes $2 \pi$ jumps phase variety due to flattening earth and topography effect. Then, the unwrapped phase of deformation can be retrieved. The Statistical Cost Network Flow Algorithm did the phase unwrapping step for Phase Unwrapping (SNAPHU) [14].

After the 74 of unwrapped interferograms have been successfully generated, they can be processed by using the SBAS method to get the LOS displacement velocity and cumulative displacement time series. The velocity was solved by the mathematical instrument called the Singular Value Decomposition (SDV) method. SDV aims to provide a Least Square Inversion solution in a linear inversion system [9] [10]. Finally, we obtained the deformation velocity $(\mathrm{mm} / \mathrm{yr})$ and the 28 of accumulated time-series displacement from Mei 2015 to September 2017.

\section{RESULTS AND DISCUSSION}

The phase difference from the conventional DInSAR process has four contributions from different sources that must be estimated and removed. Those contributions are flat-earth phase contribution due to the earth curvature, topographic contribution, the atmospheric contribution due to humidity, temperature and pressure change between the two acquisitions, and noise due to temporal change of the scatterers, different look angle, and volume scattering. After the removal of those effects, we obtained the displacement phase (deformation) contribution in the interferometric phase. Through the SBAS processing, then LOS displacement velocity was estimated.

Fig. 5 shows the LOS displacement velocity between May 2015 and September 2017 over Surabaya. From the figure, the rate of LOS displacement velocity varies from -40 to +30 $\mathrm{cm} / \mathrm{yr}$. The North area of Surabaya is experiencing significant subsidence, especially in the industrial area and warehouses in Asemworo. The deformation pattern in the East and South parts of Surabaya also dominated by subsidence. The land subsidence mostly occurred in the area near mangrove and fishpond where is in Gunung Anyar, East Surabaya. On the other hand, the area in West of Surabaya experiences uplift.

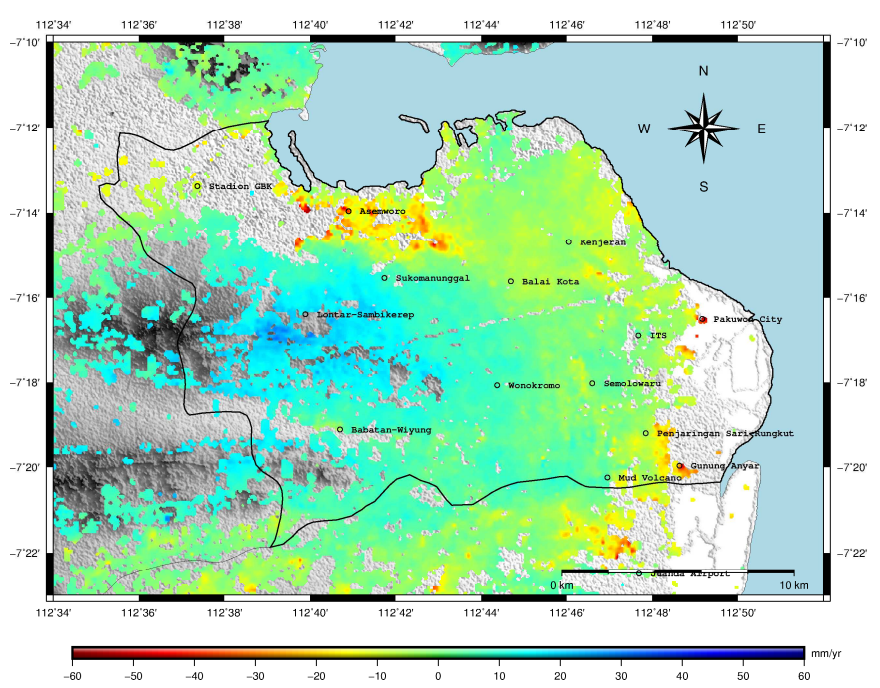

Fig. 5 LOS Velocity of Displacement (mm.yr) in Surabaya between May 2015 and September 2017, the black circles shows the landmarks

Based on the result, as shown in Fig. 5, then we focus our study on four different areas in Surabaya (see TABLE II). The distribution of the areas can be seen in Fig. 6 .

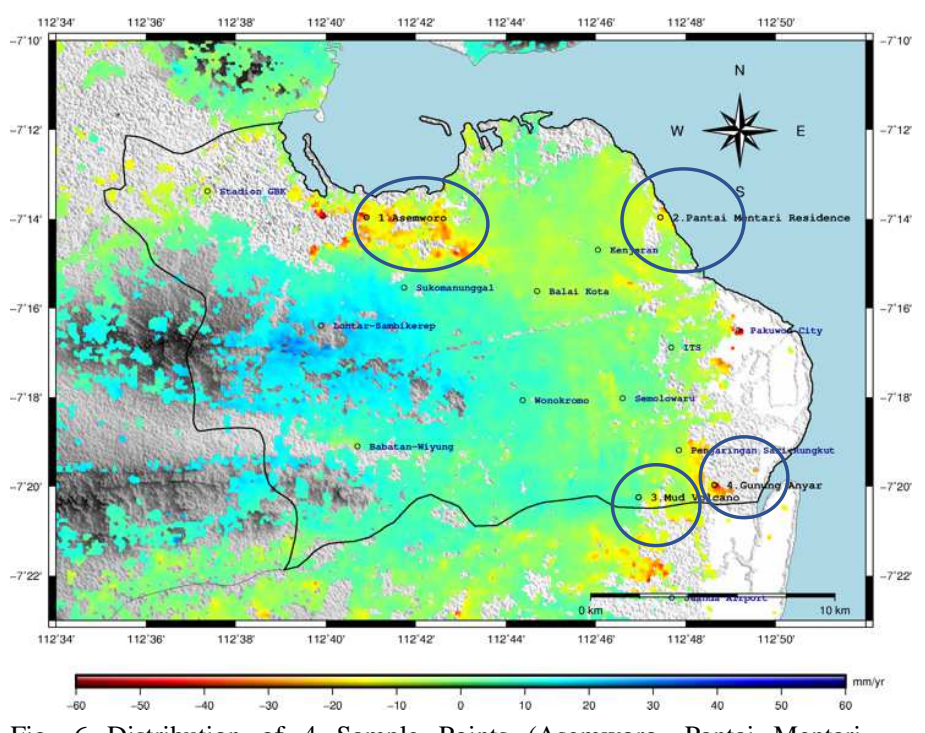

Fig. 6 Distribution of 4 Sample Points (Asemworo, Pantai Mentari Residence, Mud Volcano, and Gunung Anyar. 
TABLE II

The Los Velocity OF AT Four DifFERENT AREA

\begin{tabular}{|l|l|l|l|r|}
\hline No & Area & Longitude & Latitude & $\begin{array}{r}\text { LoS Velocity } \\
(\mathbf{m m} / \mathbf{y r})\end{array}$ \\
\hline 1. & Asemworo & 112.681 & -7.232 & -45.531 \\
\hline 2. & Pantai Mentari & 112.790 & -7.232 & -16.918 \\
\hline 3 & Mud Volcano & 112.811 & -7.332 & 0.360 \\
\hline 4 & Gunung Anyar & 112.782 & -7.337 & -31.089 \\
\hline
\end{tabular}

\section{Asemworo District}

Fig. 6 shows significant subsidence in Asemworo between May 2015 and September 2017. The rate of LOS displacement velocity is up to $-45 \mathrm{~mm} / \mathrm{yr}$. It shows that the industrial and warehouse area is potentially to experience land subsidence. Apart from the soil type of this area, which is alluvium (Fig. 1), industrial activities such as the traffic that dominated by trucks and heavy load vehicles are the trigger of the subsidence.

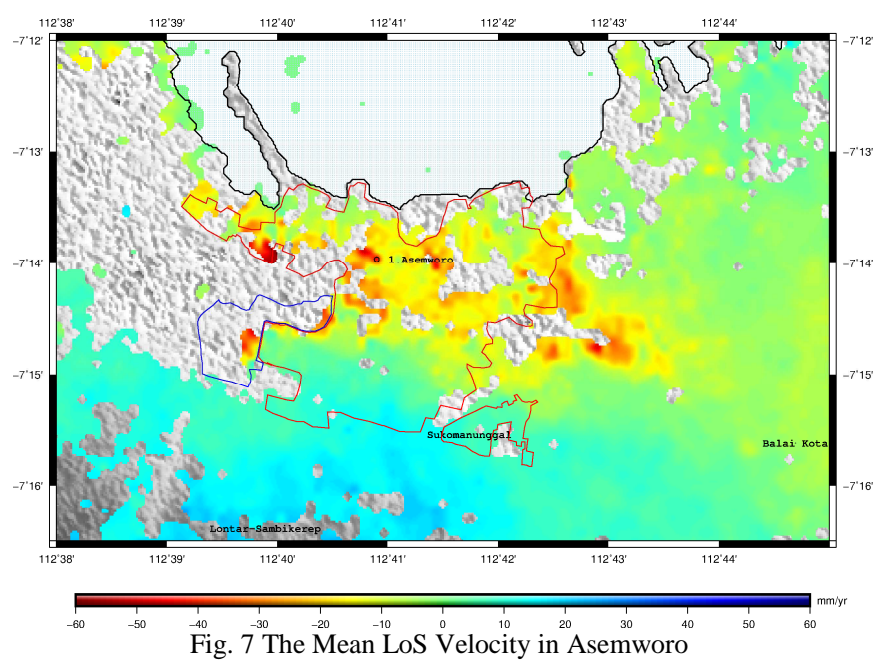

Fig. 8 shows the condition of Margomulyo Street in the Asemworo district. We found the asphalt road and the building has been damaged by the and subsidence.

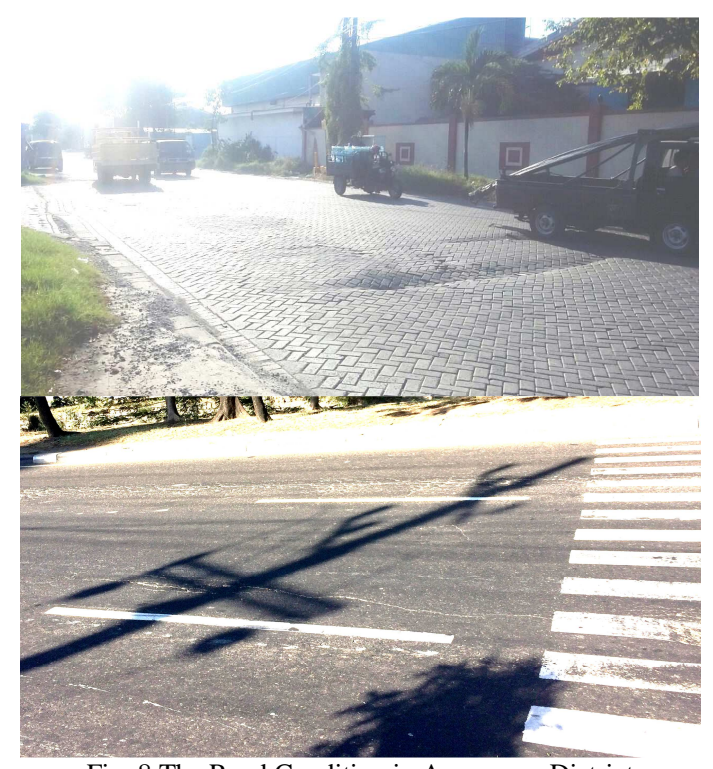

Fig. 8 The Road Condition in Asemworo District

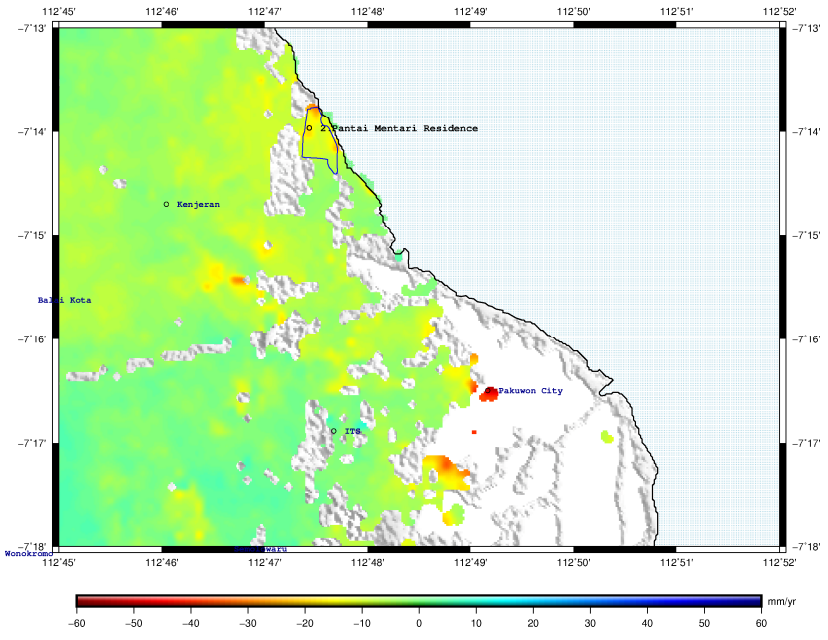

Fig 9. The Mean LoS Velocity in Kenjern

\section{Pantai Mentari, Kenjeran}

Pantai Mentari residential area, which is in Kenjeran, is divided into some clusters, and one of them was developed in 2014. The SBAS results indicated subsidence up to -16.9 $\mathrm{mm} / \mathrm{yr}$ in this area. We found fractures on the river banks in the area indicate the ground movement (Fig. 10). This area is located very close to the coast and probably built is on the sedimentation plain that still in the consolidation process. Therefore, we suspect the factor that caused the subsidence is the geological condition and increasing load due to the settlements.

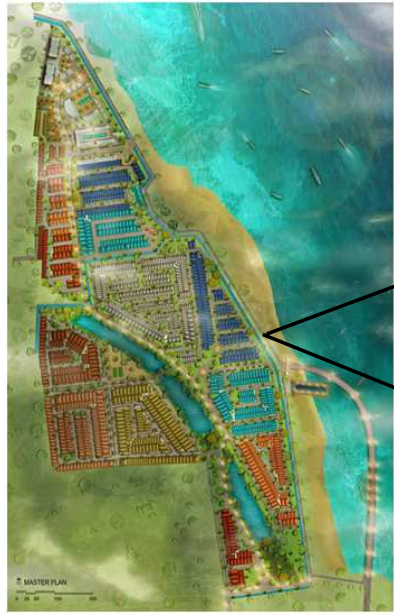

(a)

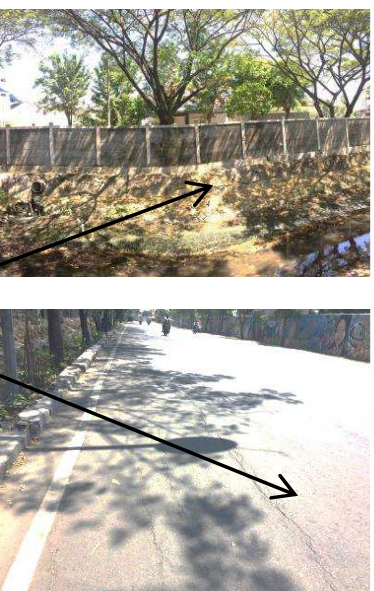

(b)
Fig. 10 The Road Condition Around Kenjeran Street

\section{E. Mudflow in Gunung Anyar.}

Mud volcano located in Watukosek fault consists of mud volcano of Sidoarjo, Porong, Pulungan, Karang Anyar, Gunung Anyar, and Socah. Mudflow of Sidoarjo and Gunung Anyar are potentially catastrophic because these are in densely populated settlements [15]. The unstopping production of mud leads the land rising [16]. As can be seen in TABLE II, this location has experienced ground movement with a small rate of uplift up to $+0.36 \mathrm{~mm} / \mathrm{yr}$. According to the locals, the discharge of mudflow volume is uncertain and unpredictable every time. When the discharge is large, this will spill over the road around the settlement, that is why the road was damaged in some area (see Fig. 11). 


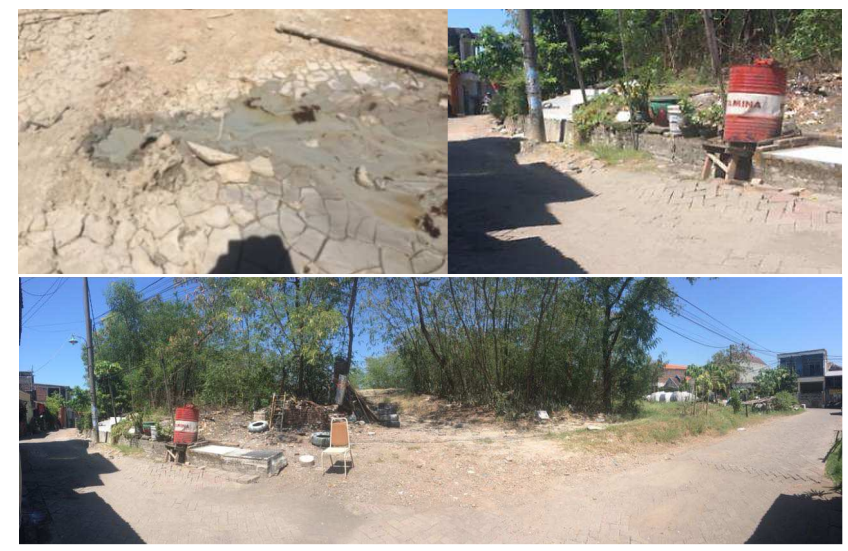

Fig. 10 The Mudflow Location and The Road Condition in Around of Gunung Anyar Mud Volcano

\section{F. Gunung Anyar Tambak}

Gunung Anyar Tambak, Wonorejo, and Medokan Ayu are located on the East Coast of Surabaya. Around 2500 hectares of the area are mangroves. However, 2300 hectares of the area has changed from fishponds and mangroves into settlements. The reclamation project had been conducted since 2010 in the East and North Coast of Surabaya. From the SBAS processing result between May 2015 and September 2017, the Gunung Anyar area experienced substantial subsidence up to $31.089 \mathrm{~mm} / \mathrm{yr}$.

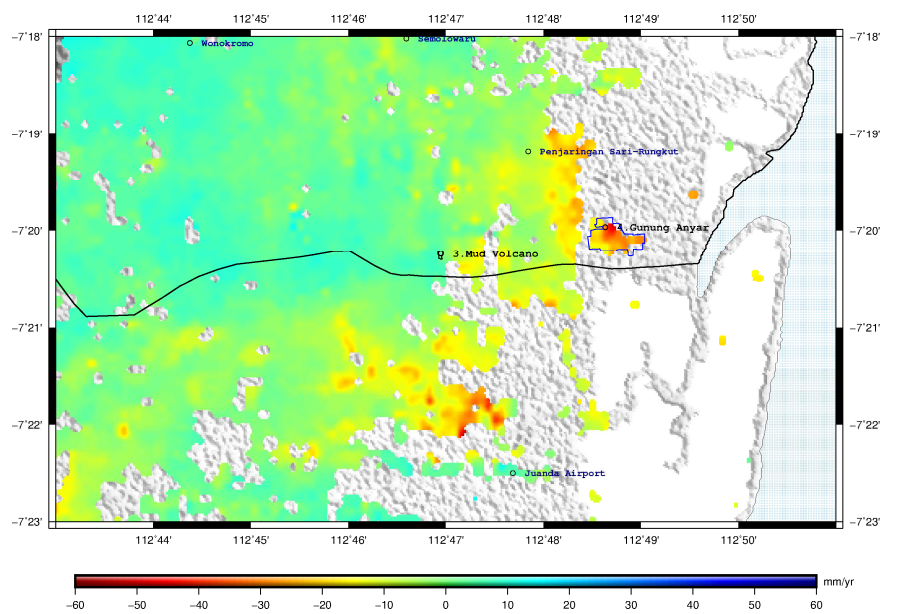

Fig 11. The LoS Velocity in Gunung Anyar Region

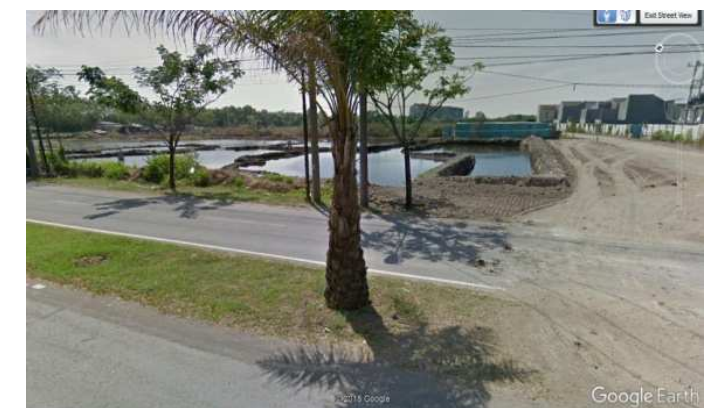

Fig 12. Fishpond before experienced the land use changes in 2014

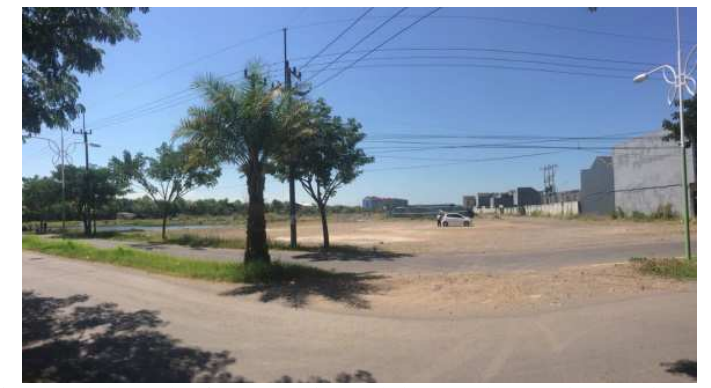

Fig 13. Fishpond After Experienced the Land Use Changes in 2018

The land-use changes cause the subsidence in this area. This area has a wide fishpond in 2014 (see Fig 12), but nowadays, most of the area has been filled by sand for the developer's needs (see Fig. 13). Furthermore, based on its geological condition, Gunung Anyar is situated on the unconsolidated alluvium plains and still in the compaction process. The increasing loads due to the continuing development of infrastructure could worsen the subsidence.

\section{CONCLUSIONS}

We studied the land subsidence phenomenon in Surabaya between May 2015 and September 2017 by using Timeseries InSAR (SBAS) method. This SBAS is operated by the SDV method that is solved by a Least Square Inversion solution in a linear inversion system. The results show two crucial information; LOS displacement velocity ( $\mathrm{mm} / \mathrm{yr})$ and consecutive time series displacement. We conclude that the rate of LOS velocity in Surabaya during May 2015 and September 2017 was about $-40 \mathrm{~mm} / \mathrm{yr}$ to $+30 \mathrm{~mm} / \mathrm{yr}$. The most significant subsidence occurred in North and East parts of Surabaya, which are Asemworo, Kenjeran, and Gunung Anyar. The land subsidence in the South of Surabaya was smaller than the North and South areas. On the contrarily, most areas in the West part of Surabaya showed uplift. After the field check, we found that most of the land subsidence occurred in the industrial and residential areas. Most of the residences in the East of Surabaya were built in the area near mangroves and the coast.

The SBAS method, which was applied in this research, is useful for detecting the deformation phenomenon in the urban due to the rapid urban growth. However, the SBAS method is less effective in highly vegetated environments because of the decorrelation. The pixels with high decorrelation (low coherence) are typically excluded from the analysis and diminished the spatial coverage in the result of TSInSAR maps.

\section{REFERENCES}

[1] Amelung, F. et al., 1999. Sensing the Ups and Down of Lav Vegas: InSAR Reveals Structure Control of Land Subsidence and AquiferSystem. Geology, Volume 27,6, pp. 483-486.

[2] Dang, V. K. et al., 2014. Recent Land Subsidence Caused by The Rapid Urban Development in The Hanoi Region (Vietnam) using ALOS InSAR Data. Natural Hazard and Earth System Science, Volume 14, pp. 657-674

[3] Bouraouli, S., 2013. Time Series Analysis of SAR Images Using Persistent Scatterer (PS), Small Baseline (SB) and Merged Approaches in Regions with Small Surface Deformation. France: Universite de Strasbourg.

[4] Chaussard, E., Amelung, F., Abidin, H. \& Hong, S. H., 2013. Sinking cities in Indonesia: Alos Palsar Detects Rapid Subsidence 
Due to Groundwater and Gas Extraction. Remote Sens. Environ, Volume 128, pp. 150-161.

[5] Gabriel, A. K., Goldstein, R. M. \& Zebker, H. A., 1989. Mapping Small Elevation Changes Over Large Areas: Differential Radar Interferometry. Geophys, Volume 94, pp. 9183-9191.

[6] Zebker, H. A. \& Villasenor, J., 1992. Decorrelation in Interferometric Radar Echoes. IEEE Trans, Volume 30, pp. 950-959.

[7] Biswas, K., Chakravarty, D., Mitra, P. \& Misra, A., 2017. SpatialCorrelation Based Persistent Scatterer Interferometric Study for Ground Deformation. Indian Soc. Remote Sensing, Volume 45, pp. 114.

[8] Lanari, R. et al., 2004. A Small-Baseline Approach for Investigating Deformations on Full-Resolution Differential SAR Interferogram. IEEE Trans. Geosci. Remote Sens, Volume 1377-1386, p. 42.

[9] Berardino, P., Fornaro, G., Lanari, R. \& Sansosti, E., 2002. A New Algorithm for Surface Deformation Monitoring Based on Small Baseline Differential SAR Interferograms. IEEE Trans. Geoscience and Remote Sensing, Volume 40 No. 11, pp. 2375-2383.

[10] Schmidt, D. A. \& Burgman, R., 2003. Time-dependent Land Uplift and Subsidence in the Santa Clara Valley, California, From A Large Interferometric, Synthetic Aperture Radar Dataset. Journal of Geophys, Volume 108, pp. 8534-8543.
[11] Zan, F. D. \& Guarnieri, A. M., 2006. TOPSAR: Terrain Observation by Progressive Scans. IEEE Trans. Geosci. Remote Sens, Volume 44, pp. 2352-2360.

[12] ESA, 2013. Sentinel-1 User Handbook. GMES-OP-EOPG-TN-130001,1st ed. s.1.: European Space Agency.

[13] BPS Surabaya, 2012. Kota Surabaya Dalam Angka. In: Surabaya: Badan Pusat Statistik Surabaya.

[14] Chen, C. W. \& Zebker, H. A., 2000. Network Approaches to TwoDimensional Phase Unwrapping; Intractability and Two New Algorithm. JOSA A 17, Volume 3, pp. 401-414.

[15] S, K. A. \& Santosa, B. J., 2016. Identifikasi Pola Persebaran Sumber Lumpur Bawah Tanah pada Mud Volcano Gunung Anyar Rungkut Surabaya Menggunakan Metode Geolistrik. Jurnal Sains dan Seni ITS, Volume 5 (1), pp. 2337-3520.

[16] Krisnayanti, B. D. \& Agustawijaya, D. S., 2014. Characteristics of Lusi Mud Volcano and Its Impacts on the Porong River. Degrade Min. Land Manage, Volume 1 (4), pp. 207-210.

[17] Supandjono J B, Hasan K, Panggabean H, Satria D and Sukardi, 1992. Geology Map of Indonesia, Sheet: Surabaya and Sapulu (Badan Geologi Indonesia) 